\title{
It's good to talk
}

\section{Media training workshops are aiming to break down the barriers between scientists and journalists}

Soon after the birth of Dolly the Sheep, Jim McWhir from the Roslin Institute in Edinburgh arrived in Spain, where he was ushered into an unscheduled press conference. After some difficult questions about cloning, he was asked about a report that had appeared that morning in the Spanish press in which an American scientist claimed that, in the near future, men would be able to get pregnant. 'I replied that I was not familiar with the work but that I wasn't about to lose any sleep worrying about getting pregnant,' said McWhir, describing the experience. 'So after being grilled about lots of serious issues, all that appeared on the Spanish news that evening was 10 seconds of me saying that I wasn't worried about getting pregnant.'

When science hits the headlines in instances like these, the wide gulf between scientists and the media is cringingly apparent. The problems start when a science story sprouts legs and walks from the laboratory to the news desk to become a hastily constructed article more about politics, health or ethics. From many scientists' point of view, the publicity resulting from such coverage can be damaging, with the release of unpublished results, equal weight given to the scientific consensus and a minority opinion, and the word 'breakthrough' appearing far more frequently than it deserves. This very loss of control over the outcome of media encounters leads many scientists to be reluctant to even speak to journalists in the belief that they are exploitative, manipulative and-the ultimate sininaccurate in their representation of the facts.
Clearly, the media places a different emphasis on current events, but Pallab Ghosh, a science correspondent of the $\mathrm{BBC}$ and Chairman of the Association of

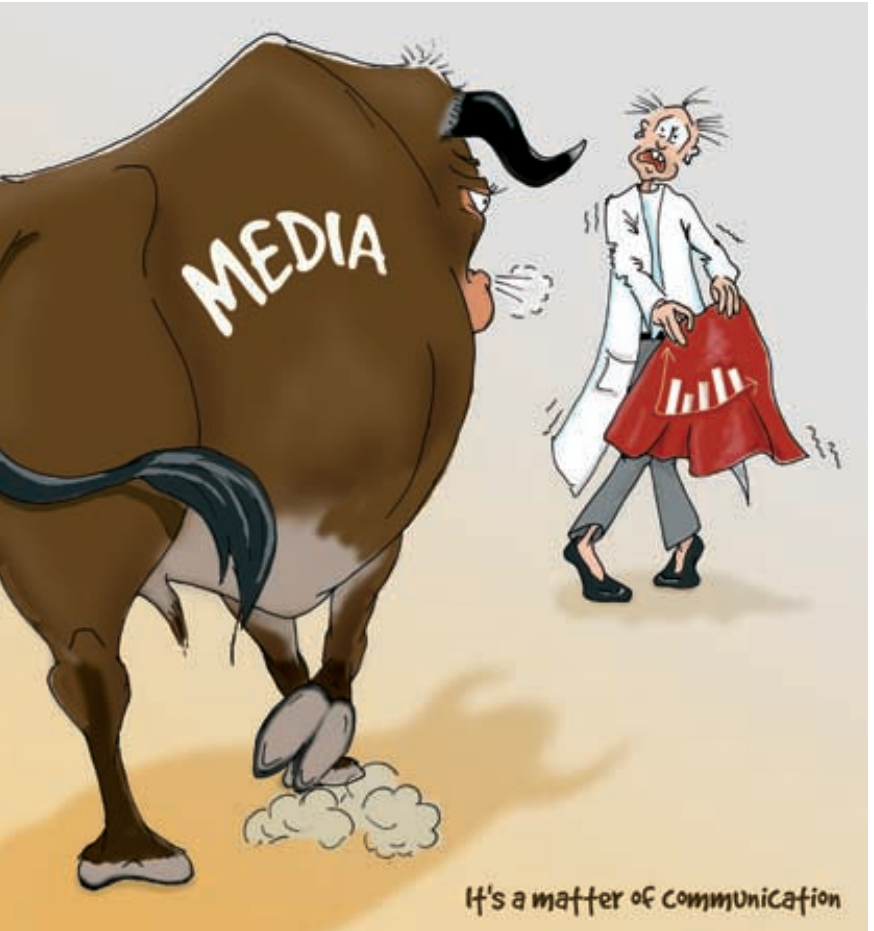

British Science Writers, believes that this should be viewed more positively. 'It's not a perfect system, but this is the price you pay for a free media,' he said. Furthermore, Ghosh feels that scientists

going to change it, nor should you really want to.' This is at a time when an increasingly critical public is questioning scientific advances and their application in new technologies. Society fears the rapid developments taking place and needs to be informed about science and its ethical implications; publicly funded scientists are increasingly being held to account by the taxpayer. Since newspapers, television and radio are such powerful means of reaching the public, it is vital that scientists are willing and able to work effectively with journalists. Equally, the style of the media may not change, but journalists could be made more aware of the scientific world, where yes/ no answers are rare, 'guaranteed safety' does not exist and disagreement amongst scientists is an essential part of the process. By bringing both factions together, media training workshops aim to break down these cultural barriers and improve the quantity and quality of science reporting to the public.

A typical workshop would convene a small number of scientists with journalists from print, radio and television for 1 or 2 days to discuss what makes a story

The problems start when a science story sprouts legs and walks from the laboratory to the news desk to become an article more about politics, health or ethics

should try to accept and understand the media and, rather than retreating into the laboratory, use it to their advantage. 'Trying to change the media is like a mosquito trying to stop an express train. You're not newsworthy, the common features and the subtle differences between each sector of the media, and to practice and analyse role-playing interviews. David Derbyshire from the UK's Daily Telegraph 


\section{analysis}

has taken part in many such courses and feels that they are beneficial for all participants. 'Scientists can find out how news organisations work and how the pressures of time and space affect what we do.' Moreover, it's a two-way process.
Clearly, there is a significant number of people who are seeking information, and the media is the obvious conduit for this.

Furthermore, as science is increasingly competitive, bringing specific topics of research to the attention of the public and

\section{Bringing specific topics of research to the attention of the public could literally pay dividends}

'Media workshops also give journalists a chance to listen to scientists and any queries or complaints that they might have about the way the media does and doesn't work.'

These are now being provided by a variety of sources: many universities, institutes and funding bodies, such as The Wellcome Trust and the Biotechnology and Biological Sciences Research Council (BBSRC) in the UK and the Deutsche Forschungsgemeinschaft (DFG) in Germany, are recognising their value, and a whole industry of professional 'communication' companies has spotted this niche in the market. Andrew McLaughlin from the BBSRC organises their 2-day media training workshops, which, he says, are enjoyed by scientists and journalists alike. The number of participants initially increased and has now plateaued, mainly because some universities are starting to run their own courses, thinks McLaughlin. 'But we have a specialised niche providing in-depth focus on biological issues,' he added. They also run workshops under the heading 'Communicating with the Public' involving radio journalists, and these tour the country visiting specific institutes. For example, the BBSRC held a workshop in the Institute of Arable Crops Research specifically tailored to genetically modified crops.

For such sensitive topics as GMOs, cloning and stem cell research, the public's understanding of science-and, more importantly, their approval-is vital for continuing progress. Fortunately, opinion polls consistently find that the public is hungrier than ever to read about science: the Eurobarometer survey in 2001 (http:// europa.eu.int/comm/research/press/2001/ pr0612en-report.pdf), for example, found that $45.3 \%$ of the Europeans questioned were interested in reading about science, whereas this figure drops to $41.3 \%$ for politics and $37.9 \%$ for economics. But, for science, only $33.4 \%$ of the population considered themselves to be well informed.

politicians could literally pay dividends. Indeed, Winfried Göpfert, an experienced science journalist and Professor of Publishing and Communication at the Freie Universität, Berlin, has seen a growing interest among scientists in his media workshops. He is currently involved in media training on average once every 2 months, but this is increasing. 'Scientists are much more in favour of approaching the media now that funding is scarce, Göpfert said. 'The reason for this is that they have no PR machine. Scientists are the only PR people for science.' This is in contrast to the USA, where universities and research institutes tend to have fully staffed press offices and experienced press officers. If an important or interesting paper is due to appear in a journal or be presented at a conference, the press office will contact the authors, write a detailed, usable press release and post it in advance on Eurekalert (the AAAS's journalist web service). Correspondingly, media workshops are much less common. 'The culture in America is very different,' concurred Derbyshire. 'In Europe there are a handful of good university press officers, but the majority of universities appear to believe they have no responsibility for communicating science to the public. Which is slightly puzzling considering how research tends to be funded.' Similarly, environmental NGO's such as Greenpeace are very skilled in attracting

\section{Oversimplification is often cited by scientists as the cause of their frustration with science reporting}

publicity, and the counter-arguments to their influential campaigns need to be presented equally effectively.

Consequently, scientists need to be able to collaborate with the media, but one of the most obvious barriers to this is language. 'Most scientists have many difficulties in avoiding jargon and scientific terms,' said Göpfert. To be plucked from a world dedicated to understanding biological principles in molecular terms and dropped into one where transcriptional repressors of genes are now dimmer switches on lights can indeed be quite a challenge. The experience and subsequent analysis of the role-playing interviews can thus be invaluable for any form of science communication, not only with the media. Nevertheless, what often prevents scientists from explaining their research in this way in a real-life situation is the fear of being scorned by colleagues: oversimplification is often cited by scientists as the cause of their frustration with science reporting. 'I don't believe it is oversimplified,' said Göpfert. 'Why call it oversimplified? It's just simplified.'

But more than simply learning how to translate research into easily understandable soundbites, scientists need to understand how the media operates. Derbyshire said that, during the workshops, 'It can come as a surprise, for instance, that most daily newspaper journalists have about two hours and 600 words for each story-and that includes researching the background, carrying out interviews, writing it up and checking the facts.' This pace is often not appreciated by scientists; while most journalists would not object to some preparation time following a 'cold' telephone call, their deadlines are strict and must be met. Andrew Flaus, a postdoc at the University of Dundee who recently attended an EMBO media workshop, felt that one of the things he learnt during the day was to provide journalists with content in such a way that it can be used immediately. 'Pre-preparation is important, and is exactly why small media workshops where everyone gets to see the pattern and practice are so valuable.'

Included in this preparation must be not only answers to the obvious questions that a journalist may ask, but also

thoughts about the wider implications of the subject. Being on the receiving end of a journalist's line of questioning when they are shaping a story can be disturbing when it's not exactly clear what turn the conversation will take next. Mark Tester, a scientist from the Department of Plant Sciences, Cambridge, was recently in the media spotlight for being the scientific 


\section{Abridged version of the Royal Society's guidelines for scientists working with the media}

(The complete version can be found at http://www.royalsoc.ac.uk)

Perspective. Think carefully about who the journalist represents (e.g. broadsheet or tabloid newspaper) and how this might affect the way your work is reported.

Deadlines. Respect the very real deadlines to which journalists must adhere and respond promptly to any enquiries. Ask for preparation time if needed, but keep this to a minimum.

Competition. Articles that are eventually featured are chosen by the editor from the many written that day. Supply interesting details to the journalist to give your story the edge that catches the editor's attention.

Content. Explain your work in simple, everyday language and think imaginatively about the implications and applications of your research.

Approach. Give a lucid and succinct overview of your work to the journalist, even if they have a science background, to help them save time researching information.

Responsibility. Do not exaggerate the significance of your work, and do not be pressurised into giving a yes/no answer if this is not appropriate.

Attribution. Avoid hiding facts by using the phrase 'No comment'. Be careful when talking 'off the record', since it can be obvious who supplied unattributed information.

Authenticity. Let the journalist know if your work has been subject to peer review.

Credibility. Be clear about your direct area of expertise and whether your comments lie outside it. Suggest names of other scientists who work in a more relevant field.

Quotes. If you would like to check your quotes, agree this beforehand and make sure you are easy to contact. Since headlines are written and stories often cut by the sub-editor, it is usually not possible to check the final article.

Interviews. Find out the angle of the interview and the type of questions to be asked, whether it is taped or live and whether it is a panel discussion or whether only a short soundbite is required.

Collaboration. Agree with collaborators what can be said to the media. Give appropriate credit, but it is not necessary to mention all involved.

Contacts. If a journalist approaches you, take their full contact details, as you might wish to contact them later with another story.

Corrections. If a mistake has been made, contact the journalist or the responsible editor, or write a brief, entertaining letter to be published. Contact the relevant 'watchdog' if necessary.

consultant for a BBC drama that portrayed a 'superbug' outbreak caused by the horizontal transfer of a multi-resistant gene from genetically modified plants. The final programme was vehemently criticised by many scientists, including Tester himself, who maintains that his advice was ignored. Previously, he had participated in one of the BBSRC's media training courses and feels that the experience was constructive for handling the sudden burst of attention. 'I found it very useful as it provided me with more techniques for when the time came. It reinforced previous training I had done and helped me to spot tricks and anticipate trouble more easily.'

Such 'tricks' are common in the reporting destined for the widely read news section, compared with that of the specialist science section, but Ghosh defends this style of journalism. 'The media isn't there to enthuse, it's there to challenge and question what is going on in the scientific community. My job is not so much to explain in an artful manner, but to reflect the debate that's going on both within the scientific community and in the wider society. That's the difference between journalism and propaganda.' This context-driven side of the media is often a revelation to scientists when they face questions in the training workshops concerning issues that they consider peripheral to their work. 'Most of us would feel objective science is distinct from our opinions on moral-ethical issues extending from the research,' Flaus commented. 'Journalists don't distinguish between scientists as individuals and the entirety of their work, so you must have a response ready for all reasonable moral and ethical dimensions.'

While undoubtedly useful, these workshops can, however, provide little more than a brief glimpse into the machinations of the media. 'A one-day media workshop is like a one-day workshop in physics. You can spend a lifetime learning about the media,' commented Ghosh. Nevertheless, journalists tend to rise in the estimation of scientists through this informal contact, and full advantage should be taken of these opportunities. 'If research is funded by the taxpayer, I believe researchers have a duty to explain to the public what they are doing. Workshops can help this communication,' said Derbyshire. Tester agreed: 'Such courses should be available to all scientists. I strongly believe scientists should engage in public debates and work actively to try to educate/inform the general public about key issues such as risk perception and the scientific process.' But even though most scientists agree that they share this responsibility, relatively few take part in any training to ensure that this can be done in the most effective way. A MORI poll in 2000 commissioned by The Wellcome Trust showed that only $10 \%$ of scientists had participated in any such media training.

It is a common complaint that scientists are treated unfairly by the media, but many other professions feel equally aggrieved. A key difference is that some people in other sectors, such as politicians and businessmen, have reacted by learning how to use the media to their best advantage. 'It's all about how you manage these situations. If a headline has got hold of the wrong end of the sticklearn how to use the 24-hour news programmes which are increasingly more influential,' said Ghosh. With the current demand for information in all areas, these dedicated news channels are providing more in-depth analysis of topical issues and would welcome contributions to a wider debate. 'If there's a mistake, you've got air-time to deal with it. 24-hour news channels are hungry for information,' he said. Only with experience, preparation and the insight gained through personal contact with the media can this channel of communication with the public be exploited to the full. As Ghosh concluded, 'See it as an opportunity to shine, not cower.'

\section{Susan R. Owens}

DOI: 10.1093/embo-reports/kvf167 